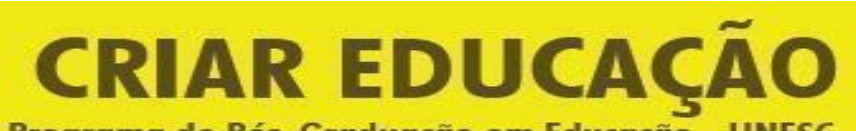

Revista do Programa de Pós-Graduação em Educação - UNESC

Criar Educação, Criciúma, v. 9, № 3, ago/dez. 2020 - PPGE - UNESC - ISSN 2317-2452

\title{
APRESENTAÇÃO DOSSIÊ ESTAR VIVO: APRENDER
}

\author{
Fernanda Monteiro Rigue ${ }^{1}$
}

Alice Copetti Dalmaso²

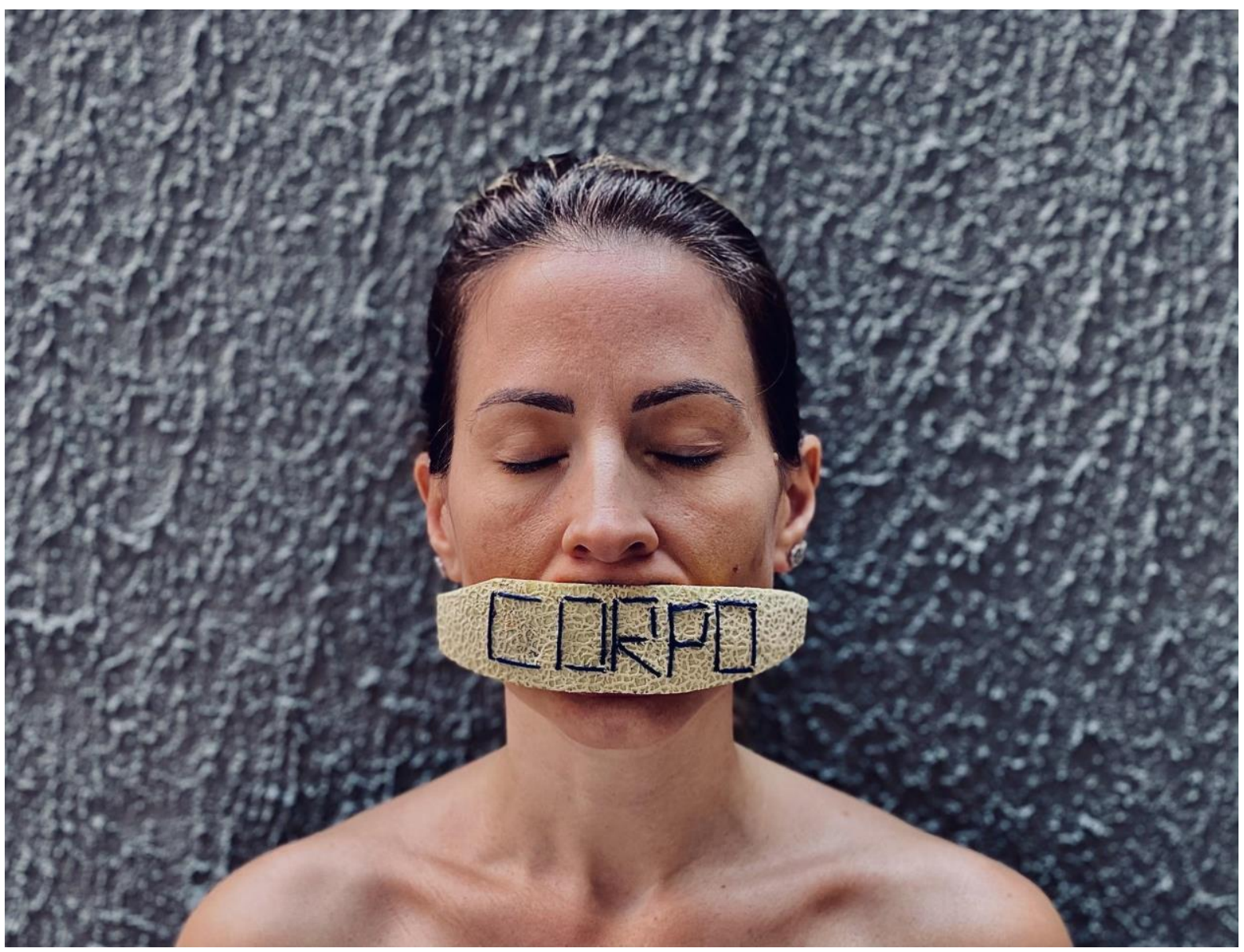

Foto: Marcos Gabriel dos Santos,2020.

Dossiê Estar vivo: aprender, Volume 9, Número 3, da revista Criar, emerge dos desassossegos em que as situações e forças mundiais contemporâneas têm

\footnotetext{
${ }^{1}$ Doutora (2020) e Mestra (2017) em Educação pelo Programa de Pós-graduação em Educação da Universidade Federal de Santa Maria. Licenciada em Química (2015) pelo Instituto Federal Farroupilha - Campus São Vicente do Sul. E-mail: fernanda_rigue@hotmail.com.

2 Professora Adjunta do Departamento de Metodologia do Ensino, do Centro de Educação, da Universidade Federal de Santa Maria (MEN/UFSM). Doutorado e Mestrado em Educação (PPGE/UFSM). Bacharel e Licenciada em Ciências Biológicas (UFSM). E-mail: alicedalmaso@gmail.com
} 
colocado a todos nós, solicitando-nos um intervalo-suspensão, convidando-nos a resingularizarmos em nós novas configurações sociais, econômicas, relacionais, educacionais, novos modos de existir. Pensamos que aí reside alguma coisa que talvez não saibamos nomear ainda, devires que tratam de processos de aprendizagens em curso, na obscuridade de não saber, afinal, o que se está aprendendo enquanto habitamos a intensa zona de indeterminação atual, verdadeiras passagens vivas, fluxos que não se pode deter, acontecimentos que chamam e perduram.

Estar vivo tem sido, entre tantas coisas, um processo de aprender a ler 0 mundo. $\mathrm{O}$ que o mundo tem nos pedido, aconselhado? Como a nossa casa, as pessoas, a escola, as crianças, os velhos, a fome, as matas e os animais, as chuvas, os ventos, a doença, os vírus, a morte, músicas, obras, seres humanos e nãohumanos, coisas de toda ordem e lugar, com as quais habitamos a nossa existência, tem nos convocado a entrar numa relação de aprender? Como nos tornamos capazes de responder ao que o mundo vem nos dizendo? Qual o apelo que tem chegado até nós, pedindo criações micro corporais e subjetivas de nossos gestos, palavras, ações? Como tornar matéria de expressão esse aprender indeterminado e aberto? Como, afinal, isso nos leva a dar a ver e dizer sobre educação?

Concebemos o estar vivo como um processo ininterrupto de criação, fabricação de si, inesgotável potência de aprendizagem. Os ecos desses processos são por vezes silenciosos, esquecidos, invisibilizados e perturbadores, porém, carregados de potência, de uma força multifacetada de alianças impensadas com o que quer que seja. Desejamos aqui que os sons das palavras desse viver-aprender chegue como um chamado a produzir uma inédita relação de composição com as palavras, conceitos, ideias, pensamentos, seres visíveis e invisíveis que habitam os textos dos autores e autoras deste material. Assim, ainda que sozinhas/os, estaremos ativas/os, deslizando sob as fronteiras, encontrando respiros, debruçandonos pelas bordas, criando e brincando pelas superfícies.

Apostamos na co-participação, escuta e atenção com a multiplicidade de perspectivas trazidas deste Dossiê, ampliando os meandros relativos aos infinitos 


\section{CRIAR EDUCAÇÃO}

Revista do Programa de Pós-Graduação em Educação - UNESC

Criar Educação, Criciúma, v. 9, ㄲo 3, ago/dez. 2020 - PPGE - UNESC - ISSN 2317-2452

processos de aprendizagens que podemos testemunhar. Por fim, o Dossiê, como uma grande extensão de nosso corpo - território que sente, pensa, age, experimenta a si mesmo - deseja que os estudos e pesquisas apresentados possam mover infinitos processos, autoconstitutivos, de aprender-criar-estar-vivo, evocando, em todos nós, novas maneiras de habitar o mundo e a educação.

Santa Maria, 2020. 